\title{
PENINGKATAN HASIL BELAJAR BIOLOGI MELALUI METODE PEMBELAJARAN MIND MAPPING MATERI JARINGAN DAN ORGAN HEWAN PADA SISWA KELAS XI-IPA 1
}

\author{
Imelda Santi Yuarifka \\ Prodi Pendidikan Biologi, Universitas Muhammadiyah Malang \\ E-mail: imeldasantiy0801@gmail.com
}

\begin{abstract}
The purpose of this study was to apply the Mind mapping method to increase the creativity of students' learning outcomes in Class XI Science 1 at MAN Malang 02 Kota Batu. This type of research used is Classroom Action Research is a form of study that is descriptive in nature, to improve the rational stability and actions taken and improve the conditions under which learning practices are carried out. The research procedure was carried out in two cycles with stages of planning, implementation and reflection. The data obtained in the form of observational data and the results of the first cycle test will be compared with cycle II. The results of observations of student actions during learning increased by $20.7 \%$ of the actions of students in cycle 1 of $70.7 \%$ to $91.4 \%$. The results of the mind mapping assessment in cycle 1 did not meet the mind mapping criteria with the acquisition of scores below the KKM and experienced an increase in cycle II, all mind mapping met the criteria with a value reaching KKM of 80 . For the evaluation test results there was an increase of $76.4 \%$, in the cycle I many students who completed KKM only 5 students with a percentage of $14.7 \%$ of 34 students who did not complete KKM with a percentage of $85.29 \%$, while in cycle II there was an increase namely there were 31 students who completed KKM with a percentage of $91.1 \%$ and 3 students who are incomplete with a percentage of $8.82 \%$.
\end{abstract}

Keywords: mind mapping; biology; learning outcomes.

\begin{abstract}
ABSTRAK
Tujuan dalam penelitian ini adalah untuk menerapkan metode mind mapping dalam meningkatan kreativitas dan hasil belajar siswa kelas XI IPA 1 di MAN Malang 02 Kota Batu. Jenis penelitian yang digunakan adalah Penelitian Tindakan Kelas merupakan suatu bentuk kajian yang bersifat deskriptif,untuk meningkatkan kemantapan rasional dan tindakan yang dilakukan serta memperbaiki kondisi di mana praktik pembelajaran tersebut dilakukan. Prosedur penelitian dilaksanakan dalam dua siklus dengan tahapan perencanaan, pelaksanaan dan refleksi. Data yang diperoleh dalam penelitian berupa data hasil observasi dan hasil tes siklus I yang akan dibandingkan dengan siklus II. Hasil observasi tindakan siswa selama pembelajaran meningkat 20,7\% dari tindakan siswa pada siklus I sebesar 70,7\% menjadi 91,4\%. Hasil penilaian mind mapping pada siklus I belum memenuhi kriteria mind mapping dengan perolehan nilai dibawah KKM dan mengalami peningkatan pada siklus II seluruh mind mapping telah memenuhi kriteria dengan nilai mencapai KKM sebesar 80. Untuk hasil tes evaluasi terdapat peningkatan sebesar 76,4\%, pada siklus 1 banyak siswa yang tuntas KKM hanya 5 siswa dengan presentase 14,7\% dari 34 siswa yang tidak tuntas KKM dengan presentase 85,29\%, sementara pada siklus 2 terdapat peningkatan yakni terdapat 31 siswa yang tuntas KKM dengan presentase 91,1\% dan 3 siswa yang tidak tuntas dengan presentase $8,82 \%$.
\end{abstract}

Kata kunci: mind mapping; biologi; hasil belajar.

\section{PENDAHULUAN}

Biologi merupakan salah satu pelajaran berbasis Ilmu Pengetahuan Alam yang mempelajari tentang kehidupan baik berupa struktur, fungsi maupun lingkungan suatu organisme. Salah satu materi yang

Cara mengutip: Yuarifka, I., S. (2020). Peningkatan Hasil Belajar Biologi Melalui Metode Pembelajaran Mind Mapping Materi Jaringan dan Organ Hewan pada Siswa Kelas XI-IPA 1. Inteligensi: Jurnal Ilmu Pendidikan, 3(1), 33-39 
dibahas dalam ilmu biologi adalah struktur jaringan dan organ pada hewan, yang mencakup struktur penyusun dari sederhana sampai membentuk suatu organ dan individu. Luasnya materi jaringan hewan ini, membuat siswa menjadi kurang minat dalam mempelajari materi, terjadi kesalahan konsep dalam memahami materi sehingga menyebabkan hasil akhir yang tidak memuaskan. Ketidakseimbangan antara luasnya materi dengan waktu yang tersedia menyebabkan masih ada guru yang mengajar secara konvensional melalui metode ceramah dan siswa dituntut untuk mendengar serta mencatat kembali penjelasan yang diberikan guru tanpa diberi kesempatan untuk bertanya dan berpendapat hal ini yang menyebabkan suasanan belajar dan rendahnya kreativitas serta keaktifan siswa dalam menyelesaikan tugas (Subakti, 2015).

Selain faktor sarana prasarana yang dapat mendukung proses pembelajaran, salah satu factor yang sangat mempengaruhi proses pembelajaran adalah ketepatan guru dalam memilih dan menerapkan model pembelajaran yang sesuai dengan materi. Sehingga, mampu menarik minat siswa untuk belajar, meningkatkan kreativitas dan keaktifan siswa dalam memahami suatu materi sehingga kesalahan konsep bisa di minimalisir untuk meningkatkan hasil belajar. Menurut Winkel (2005; 59), sampai saat ini proses pembelajaran masih bergantung pada metode pembelajaran yang kurang memperhatikan kebutuhan dan pengembangan potensi siswa seperti pada penggunaan guru sangat dominan dan gaya mengajarnya bersifat sebatas pada penyampaian informasi. Berdasarkan hasil observasi maupun wawancara dari beberapa siswa mengenai penerapan metode dan model pembelajaran yang pernah di laksanakan pada materi sebelumnya, guru masih menggunakan metode konvensional dengan system ceramah dan diskusi yang hanya mengedepankan pembelajaran tekstual yang sifatnya monoton menyebabkan siswa merasa bosan dan terbatas dalam berkreativitas sehingga siswa tidak bersemangat dalam belajar dan dapat mempengaruhi hasil belajar yang tidak sesuai dengan yang diharapkan. Rendahnya minat dan hasil belajar siswa karena masih dipertahankannya model pembelajaran konvensional seperti ceramah dan diskusi, guru mendominasi proses pembelajaran dengan ceramah sementara siswa berperan penuh sebagai objek dari proses pembelajaran, dimana siswa hanya sekedar mendengar, melihat dan menulis kembali penjelasan guru tanpa ada kesempatan untuk berkreasi sendiri, seperti bedah literature dari berbagai sumber dan menuliskan hasil diskusi bersama siswa lain. Hal ini belum sesuai dengan tuntutan kegiatan belajar mengajar agar proses pembelajaran dikelas aktif dan menyenangkan bagi siswa sehingga bisa meningkatkan hasil belajar siswa (Amalia dkk, 2017).

Melihat keadaan ini, maka peneliti akan melakukan tindakan kelas dengan menggunakan metode pembelajaran berbasis mind mapping yang akan dapat meningkatkan kreativitas dan hasil belajar siswa terhadap pembelajaran. Menurut Porter \& Hernacki (2008:152-159) mind mapping juga dapat disebut dengan peta pemikiran. Metode pembelajaran mind mapping yaitu pembelajaran dengan menyajikan informasi yang berhubungan dengan topic yang sangat luas dalam 
bentuk kunci, gambar, simbol, peta konsep sehingga suatu informasi dapat dipelajari dan diingat secara cepat dan efisien. Sesuai dengan kerja otak dalam mengambil informasi secara bercampuran antara gambar, bunyi, aroma, dan perasaan kemudian memisah-misahkan kedalam bentuk tulisan atau orasi. Saat otak mengingat informasi, biasanya dilakukan dalam bentuk gambar warna warni, simbol, bunyi, dan perasaan. Oleh karena itu, agar peta pikiran dapat berfungsi secara maksimal dengan warna-warni, gambar dan simbol sehingga tampak seperti karya seni. Hal ini bertujuan agar siswa mampu menulis kembali materi yang diperoleh dari berbagai sumber, sehingga siswa sudah mulai terbiasa mengorganisasikan materi yang luas menjadi lebih sederhana dengan kreativitasnya, memberikan wawasan baru, memudahkan dalam mengingat dan memahami materi dan mempengaruhi hasil belajar siswa (Afandi, 2013). Adapun tujuan yang ingin dicapai dalam penelitian ini adalah untuk mendeskripsikan penerapan metode mind mapping pada mata pelajaran biologi dalam meningkatan kreativitas hasil belajar siswa kelas XI IPA 1 di MAN Malang 02 Kota Batu.

\section{METODE PENELITIAN}

Jenis penelitian yang digunakan adalah PTK (Penelitian Tindakan Kelas) merupakan suatu bentuk kajian yang bersifat deskriptif oleh pelaku tindakan, yang di lakukan untuk meningkatkan kemantapan rasional dan tindakantindakan yang dilakukan itu serta memperbaiki kondisi di mana praktikpraktik pembelajaran tersebut dilakukan. Data yang diperoleh dalam penelitian adalah berupa data hasil observasi dan hasil tes. Prosedur penelitian dilaksanakan dalam dua siklus adalah sebagai berikut:

\section{Tahap Perencanaan Tindakan Siklus I dan II}

Pada tahap perencanaan, peneliti merencanakan pembelajaran siklus 1 dan 2 seperti yang telah direncanakan pada silabus dan RPP (Rencana Pelaksanaan Pembelajaran) di MAN Malang 02 Batu.

\section{Tahap Pelaksanaan Tindakan Siklus I dan II}

Pada tahap pelaksanaan ini, pembelajaran berlangsung sesuai dengan Rencana Pelaksanaan Pembelajaran yang diatur sebagai berikut :

a) Pendahuluan

Pada tahap ini peneliti sebelum mengemukakan apersepsi dan motivasi untuk menarik perhatian siswa agar konsentrasi dengan materi yang akan dibahas. Peneliti akan memberikan pretest untuk mengetahui seberapa besar kesiapan siswa untuk belajar materi struktur jaringan dan organ hewan.

b) Kegiatan Inti

Sesuai dengan kurikulum 2013, peneliti akan tetap menerapkan pembelajaran Scientific yaitu dengan 5M dimulai dari mengamati, menanya, mengumpulkan data, mengasosiasi, dan mengkomunikasikan.

c) Kegiatan Penutup

Peneliti dan siswa akan bersamasama menyimpulkan hasil belajar, peneliti akan memberikan post test untuk mengetahui seberapa besar tingkat pemahaman pembelajaran yang didapatkan melalui mind mapping

\section{Tahap Pelaksanaan Observasi Tahap I dan II}

Observasi dilaksanakan selama proses pembelajaran berlangsung terhadap 
aktivitas belajar siswa dan keadaan kelas selama pembelajaran dengan menggunakan metode berbasis Mind mapping. Hasil pengamatan ini digunakan untuk refleksi pada perencanaan tindakan siklus II untuk menentukan tingkat keberhasilan pembelajaran.

\section{Tahap Pelaksanaan Refleksi I dan II}

Berdasarkan data yang diperoleh dari tindakan I, maka data tersebut diolah atau dianalisis. Selanjutnya dicatat kelebihan dan kelemahan sebagai akibat dari tindakan kelebihan akan terus dipertahankan, sedangkan kelemahan yang ditemui selanjutnya diperbaiki untuk pelaksanaan siklus II hingga menunjukkan hasil yang lebih baik dengan menggunakan metode pembelajaran berbasis Mind mapping.

\section{HASIL DAN PEMBAHASAN}

Instrumen yang digunakan dalam penelitian ini adalah soal tes,lembar observasi, angket, RPP (Rencana Pelaksanaan Pembelajaran), dan lembar penilaian siswa. Untuk pengumpulan data peneliti mengambilnya dari aktifitas belajar siswa dengan melakukan pengamatan saat proses belajar mengajar dan prestasi belajar siswa di akhir penelitian dengan pemberian soal test di akhir siklus I dan II. Untuk mengetahui prestasi belajar, data yang dianalisis yaitu hasil tes formatif setiap siklus dengan menggunakan kriteria ketuntasan belajar. Siswa tersebut disebut tuntas belajar bila mencapai skor minimal 80 berdasarkan KKM MAN Malang 02 Kota Batu. Hasil observasi aktivitas siswa selama pembelajaran siklus I dan II tentang jaringan dan organ hewan dengan menggunakan metode mind mapping menunjukkan bahwa keberhasilan aktivitas siswa selama proses pembelajaran pada siklus I berlangsung menghasilkan skor rata-rata $70,7 \%$. Hal ini berarti taraf keberhasilan aktivitas siswa selama kegiatan pembelajaran termasuk dalam kategori "Baik". Sementara pada siklus II menunjukkan bahwa keberhasilan tindakan siswa selama proses pembelajaran berlangsung menghasilkan skor 91,4\%. Hal ini berarti taraf keberhasilan aktivitas siswa selama kegiatan pembelajaran selama siklus I dan II mengalami peningkatan dari kategori "Baik" menjadi kategori "Sangat Baik".

Hasil penilaian Mind mapping selama pembelajaran pada siklus I tentang jaringan hewan yang dibagi menjadi 8 kelompok menunjukkan bahwa penulisan mind mapping pada materi jaringan hewan masih belum memenuhi kriteria mind mapping, dimana mind mapping masih mengunakan kalimat dan paragraf tanpa dilengkapi gambar jaringan. Hal ini menunjukkan siswa masih belum memahami kriteria penulisan mind mapping yang benar seperti yang disajikan pada gambar 1 berikut:

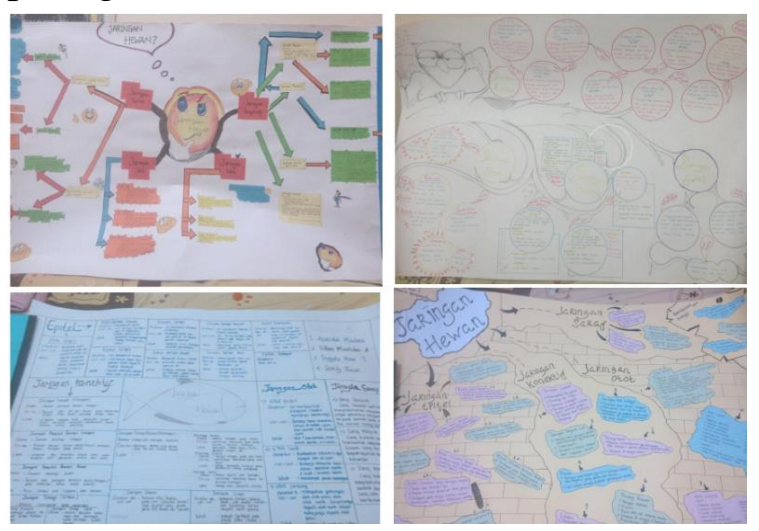

Gambar 1. Mind mapping Siklus I

Hasil mind mapping pada siklus II menunjukkan bahwa penulisan mind mapping pada materi organ dan sistem organ hewan telah memenuhi kriteria mind 
mapping, dimana mind mapping telah ditulis dalam bentuk kata kunci dengan banyak cabang pemikiran dan dilengkapi gambar-gambar penyusun jaringan pada setiap organ dalam sistem organ. Hal ini menunjukkan siswa telah memahami kriteria penulisan mind mapping yang benar yang disajikan pada gambar 2 sebagai berikut:

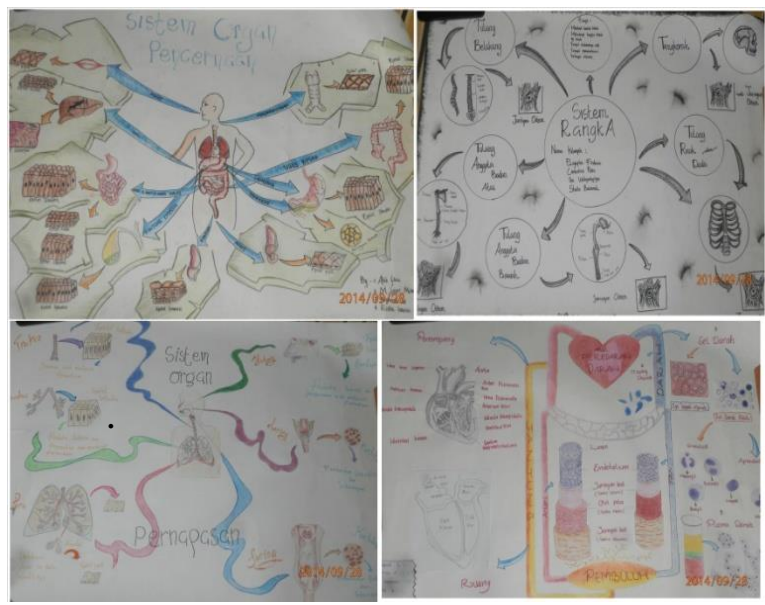

Gambar 2. Mind mapping Siklus II

Hasil nilai rata-rata tes evaluasi pada akhir tindakan 1 dapat dilihat pada tabel 1 berikut ini.

Tabel 1. Hasil Tes Siklus 1

\begin{tabular}{lcc}
\hline \multicolumn{1}{c}{ Tes Akhir Tindakan 1 } & $\begin{array}{c}\text { Banyak } \\
\text { Siswa }\end{array}$ & Presentase \\
\hline $\begin{array}{l}\text { Siswa yang tuntas belajar } \\
\text { (nilai minimal 80) }\end{array}$ & 5 & $14,7 \%$ \\
$\begin{array}{l}\text { Siswa yang tidak tuntas } \\
\text { belajar (nilai dibawah }\end{array}$ & 29 & $85,29 \%$ \\
80) & \multicolumn{2}{|c}{} \\
Banyak Siswa & \multicolumn{2}{|c}{34} \\
\hline
\end{tabular}

Berdasarkan tabel 2 dapat diketahui bahwa setelah tindakan diberikan atau saat siswa menyelesaikan soal evaluasi pada akhir tindakan 1, diperoleh keterangan sebagai berikut: (1) banyak siswa yang tuntas belajar sebanyak 5 siswa; (2) banyak siswa yang tidak tuntas belajar sebanyak 29 siswa; (3) berdasarkan kriteria ketuntasan belajar klasikal dapat disimpulkan hasil belajar siswa ditinjau dari aspek kognitif pada siklus I dikategorikan belum mencapai ketuntasan klasikal, karena presentase siswa yang tuntas belajar dibawah $80 \%$ yaitu masih $14,7 \%$. Berdasarkan hal tersebut dikatakan bahwa hasil belajar siswa belum meningkat. Untuk itu di katakan bahwa hasil belajar siswa setelah diadakannya tindakan 1 belum mencapai nilai ketuntasan, selanjutnya penelitian dilanjutkan ke siklus II. Berdasarkan hasil observasi dan tes, peneliti berusaha memperbaiki kualitas pembelajaran sehingga bisa tercapai hasil belajar yang diinginkan yaitu mencapai nilai ketuntasan klasikal diatas $80 \%$ atau sesuai dengan KKM sekolah dengan nilai sebesar 80 .

Hasil nilai rata-rata tes evaluasi pada akhir tindakan 2 dapat dilihat pada tabel 2 berikut ini.

Tabel 2. Hasil Tes Siklus 2

\begin{tabular}{lcc}
\hline \multicolumn{1}{c}{ Tes Akhir Tindakan 1 } & $\begin{array}{c}\text { Banyak } \\
\text { Siswa }\end{array}$ & Presentase \\
\hline $\begin{array}{l}\text { Siswa yang tuntas belajar } \\
\text { (nilai minimal 80) }\end{array}$ & 31 & $91,1 \%$ \\
$\begin{array}{l}\text { Siswa yang tidak tuntas } \\
\text { belajar (nilai dibawah 80) }\end{array}$ & 3 & $8,82 \%$ \\
Banyak Siswa & \multicolumn{2}{c}{34} \\
\hline
\end{tabular}

Berdasarkan tabel 3 dapat diketahui bahwa setelah tindakan diberikan atau saat siswa menyelesaikan soal evaluasi tindakan 2, diperoleh keterangan sebagai berikut: (1) banyak siswa yang tuntas belajar sebanyak 31 siswa memperoleh nilai diatas 80; (2) banyak siswa yang tidak tuntas belajar sebanyak 3 siswa yang memperoleh nilai dibawah 80. Berdasarkan kriteria ketuntasan belajar klasikal dapat disimpulkan juga hasil belajar siswa ditinjau dari aspek kognitif pada siklus II dikategorikan mencapai ketuntasan klasikal, karena prosesntase siswa yang tuntas belajar diatas $80 \%$ yaitu 
sebesar 91,1\%. Hal ini menunjukkan penelitian selesai pada siklus II. Pada siklus II aktivitas peserta didik sudah meningkat, peserta didik sudah berani mengemukakan pendapatnya, memiliki rasa sosial yang tinggi, interaksi, dan kerjasama antar peserta didik yang meningkat. Hal ini merupakan tujuan dari pembelajaran kooperatif, yaitu: meningkatkan aktivitas peserta didik, meningkatkan interaksi, meningkatkan penguasaan peserta didik terhadap materi pembelajaran dan akan meningkatkan motivasi peserta didik untuk aktif dalam proses pembelajaran (Yustini, 2005).

Mind Mapping bertujuan membuat materi pelajaran terpola secara visual dan grafis yang akhirnya dapat membantu merekam, memperkuat, dan mengingat kembali informasi yang telah dipelajari. Mind Mapping adalah satu teknik mencatat yang mengembangkan gaya belajar visual, karena terdapat gambar di dalamnya. Setiawan, dkk (2019) menyatakan bahwa gambar dapat meningkatkan kognitif siswa karena dapat membantu siswa berpikir bebas, mendorong siswa berpikir lebih fleksibel, dan juga mudah dalam mengekspresikan objek dan gagasan di atas kertas. Mind Mapping juga memadukan dan mengembangkan potensi kerja otak yang terdapat di dalam diri seseorang. Dengan adanya keterlibatan kedua belahan otak maka akan memudahkan seseorang untuk mengatur dan mengingat segala bentuk informasi, baik secara tertulis maupun secara verbal.

Mind mapping pertama kali diungkapkan oleh Buzan (2009) yang menyatakan bahwa mind mapp adalah sistem penyimpanan, penarikan data, dan akses yang luar biasa untuk perpustakaan raksasa, yang sebenarnya ada dalam otak manusia yang menakjubkan. Mind map adalah cara termudah untuk menyimpan informasi ke dalam otak dan membawa informasi keluar otak. Mind map adalah cara mencatat yang kreatif, efektif, dan secara harfiah akan "memetakan" pikiran. Windura (2008) menggambarkan bahwa mind mapping mengharuskan anak menggunakan warna dan kata dalam pembuatannya dan disukai oleh otak. Kedua belah otak pun terlibat didalamnya, anak lebih senang dalam belajar, dengan moto learning is fun. Hal ini sejalan dengan peraturan pemerintah agar pembelajaran dapat berjalan dengan menyenangkan.

\section{SIMPULAN}

Berdasarkan data hasil penelitian dan analisis data dapat disimpulkan bahwa adanya peningkatan hasil belajar peserta didik setelah dilakukannya pembelajaran dengan metode mind mapping hal ini dapat diketahui melalui data observasi pada siklus I dan siklus II. Selain peningkatan hasil belajar yang meningkat adapun aktivitas peserta didik yang meningkat meliputi peningkatan kreatifitas, keterampilan sosial, interaksi, dan kerjasama antar peserta didik, serta timbulnya keberanian mengemukakan pendapat. Khususnya untuk nilai tes evaluasi pada siklus I masih belum mencapai ketuntasan klasikal sebesar $80 \%$ yaitu hanya $14,7 \%$ sedangkan pada siklus II prosentase ketuntasan siswa telah mencapai $91,1 \%$ ini menunjukkan terdapat peningkatan hasil belajar siswa ditandai dengan meningkatnya ketuntasan belajar peserta didik pada siklus I dan siklus II.

Berdasarkan kesimpulan yang diambil, maka diberikan beberapa saran yang dapat dijadikan bahan pertimbangan 
untuk perbaikan proses pembelajaran, yaitu peneliti menyarankan agar memperluas objek penelitian yang melibatkan sekolah yang mempunyai prestasi lebih heterogen. Bagi instansi pendidikan sebaiknya menerapkan metode mind mapping pada materi-materi tertentu untuk meningkatkan kreatifitas dan prestasi hasil belajar peserta didik serta supaya peserta didik tidak merasa bosan dengan metode pembelajaran yang hanya monoton.

\section{DAFTAR PUSTAKA}

Afandi, MS. 2013. Metode Mind Mapping. Digilib.uinsby.ac.id (diakses 29 Mei 2020)

Ali, M. 2008. Guru Dalam Proses Belajar Mengajar. Penerbit Sinar Baru Algensindo, Bandung.

Amalia, B., Achmad, R. \& Lilies. 2017. Pengaruh Model Pembelajaran Kooperatif Mind Mapping dan Motivasi Belajar Terhadap hasil Belajar Siswa Tentang Biologi Di Kelas IX SMP Negeri 6 Palu. https://pdfs.semanticscholar.org/ (diakses 29 Mei 2020).

Arikunto, S. 2006. Prosedur Penelitian Suatu Pendekatan Praktik. Edisi revisi. Penerbit Rineka Cipta, Jakarta.

Ayu, A. 2011. Penggunaan peta konsep untuk mengatasi mis konsepsi materi jaringan tumbuhan. Skripsi. Jakarta :UIN Syarif Hidayatullah.

Buzan, T. 2009. Buku Pintar Mind Mapping. Gramedia. Jakarta

Chotimah, H. \& Dwitasari, Y. 2009. Strategi-Strategi Pembelajaran untuk Penelitian Tindakan Kelas. Surya Pena Gemilang, Malang.

Djamarah, S., B \& Zain, A. 2006. Strategi Belajar Mengajar. Edisi revisi. Penerbit Rineka Cipta, Jakarta.

Hamalik, O. 2003. Metodologi Pengajaran Ilmu Pendidikan Berdasarkan Pendekatan Kompetensi. Penerbit Mandar Maju, Bandung.

Hamalik, Oemar. 2004. Proses Belajar Mengajar. Penerbit Bumi Aksara, Jakarta.

Hidayati, Z. 2010. Penggunaan Metode Mind Map Sebagai upaya meningkatkan motivasi dan prestasi belajar biologi materisistem peredaran darah kelas XI Ipa 1 MAN Yogyakarta. Skripsi. Yogyakarta:UIN Sunan Kalijaga.

Ibrahim, M. 2000. Pembelajaran Kooperatif. Universitas Negeri Surabaya, Surabaya.

Setiawan, H., Aji, S.M.W., \& Aziz, A. (2019). Puisi Berbasis Karya Gambar: Upaya Penguatan Literasi Siswa SD Kelas Tinggi. Inteligensi: Jurnal Ilmu Pendidikan, 2(1), 50-60.

Surbakti, R. 2015. Upaya Peningkatan Hasil Belajar Konsep jaringan Hewan Melalui Media Flashcards pada siswa kelas XI IPA MAN 2 Skripsi. Universitas Padang.

Windura. 2008. Pembelajaran Permainan Roda Pintar pada Mata Pelajaran Administrasi Kepegawaian Kelas. Jurnal Administrasi Perkantoran (JPAP). Unesa. Vol 5, No 1

Wiriatmatmadja, R. 2008. Metode Penelitian Tindakan Kelas. Penerbit PT Remaja Rosdakarya, Bandung. 